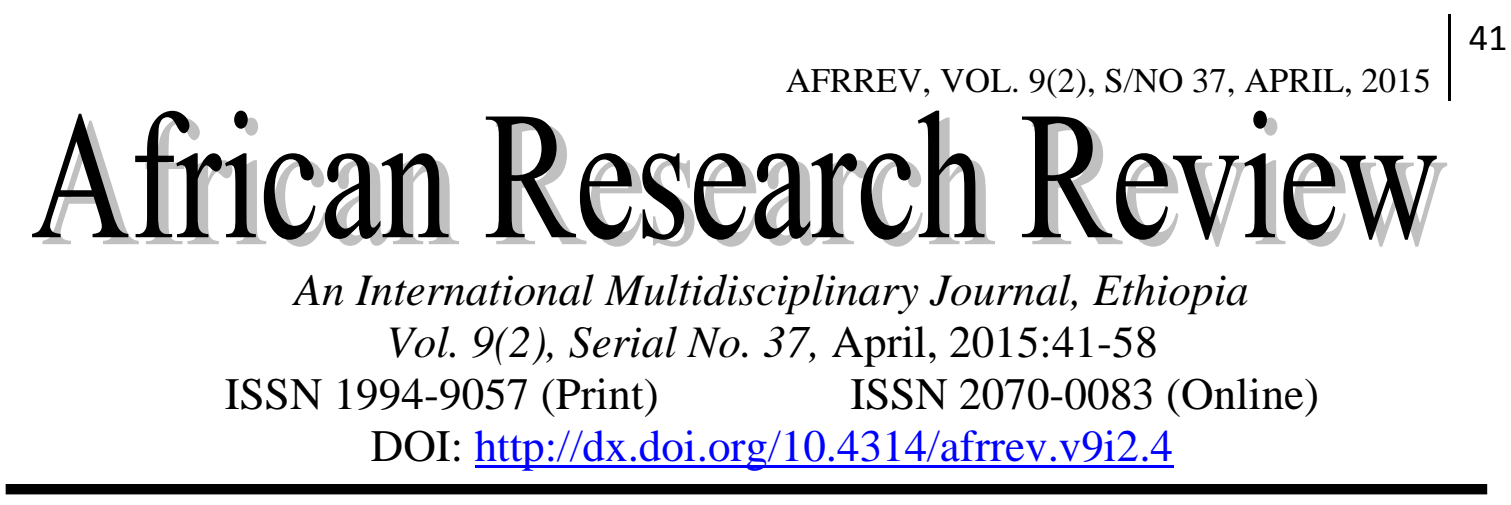

\title{
Leadership, Corruption and Governance in Nigeria: Issues and Categorical Imperatives
}

\author{
Anazodo, R.O. \\ Department of Public Administration \\ Faculty of Management Sciences \\ Nnamdi Azikiwe University, P.M.B 5025 Awka \\ Anambra State Nigeria \\ Igbokwe-Ibeto, C. J. \\ Department of Public Administration \\ Faculty of Management Sciences \\ Nnamdi Azikiwe University, P.M.B 5025 Awka \\ Anambra State Nigeria \\ E-mail: ugochinyereci@yahoo.co.uk \\ Phone: +2348112322280 \\ $\&$
}

Nkah B.C.

Department of Public Administration

Faculty of Management Sciences

Nnamdi Azikiwe University, P.M.B 5025 Awka

Anambra State Nigeria 
AFRREV, VOL. 9(2), S/NO 37, APRIL, 2015

\begin{abstract}
Nigeria is inundated with rich human and material resources begging to be harvested by purposeful, creative and innovative leadership. Leadership that is based on the cultural values of the people and takes a Bottom-top approach holds the key to unlocking the development quagmire Nigeria has found itself. However, this is not the case due to leadership failure, corruption and bad governance. Within the framework of theories of the two public and nature of society, an eclectic approach, the paper examines the issues of leadership, corruption and governance with a view to adumbrate the trajectory of an efficacious leadership and governance modus operandi capable of finding solutions to Nigeria's myriad problems. Also examined is the enigmatic nature of corruption in Nigeria that has made it a lucrative venture. The paper confirms earlier position that leadership, corruption and bad governance are the bane militating against development in Nigeria. Therefore, all hands must be on deck to enthrone effective leadership and good governance that could expunge the scourge of corruption from the nation's body polity. The first fundamental step among other measures is transformation of the state from an alien force to an entity that caters for the welfare and wellbeing of the people. Yet, the need for patriotic, visionary and missionary leaders cannot be overstated because a nation can only be great when it has leaders that plant trees whose shades they know they shall never seat in. The followers should as well perform their obligatory and non-obligatory civic duties and responsibilities.
\end{abstract}

Key words: Development, Corruption, Leadership, Governance, Transformation

\title{
Introduction
}

One of the major challenges facing Nigeria and other developing areas of the world is how to create a context of stable political and socio-economic environment for policies and programmes to be implemented. The issue of getting the right leadership to fight corruption and propel good governance has been a recurring decimal in Nigeria and Africa in general. Once this enabling environment is created, it becomes easy for the people to confront and resolve challenges facing them by using resources within their environment to create a condition of life where each stage is progressively better than the preceding one. However, this is not the case in Nigeria due to corruption and bad governance. Good governance encapsulates transparency, accountability, freedom of choice and liberty for the people to pursue their individual and corporate interest. Indeed, at the core of Africa's underdeveloped status are corruption and leadership deficit.

Leadership and good governance are crucial to realizing any giant stride taken in pursuit of development anywhere in the world, Nigeria is not an exception.

Copyright (C) IAARR, 2015: www.afrrevjo.net

Indexed African Journals Online: www.ajol.info 
The reverberation effects of the failure of leadership, corruption and bad governance are visible and being felt across all sectors and segment of the Nigerian society. Unemployment and employment for cash, insecurity, crude oil thefts, crisis in education, dearth of infrastructures such as health services, transportation, accommodation, communication, medication etc are all common features in Nigeria. It is an irony that of all oil producing nations, Nigeria is the only country with the history of crude oil thefts. Michels (in Olayiwola, 2013) posits that an examination of Nigeria's socio-economic and political history reveals that many of its leaders over the years have been using the "iron law of oligarchy" which explains the triumph of the leaders' ambitions for office over the membership's revolutionary goals.

Since the flag of political independence in 1960, Nigerian leaders and their regimes have been deeply engrossed in excessive acts of corruption and bad governance. All available means have been employed by Nigerian political leaders to 'grab' power including the blatant rigging of elections, manipulation of census figures, violence, thuggery, arson, vandalism, gangsterism, corruption, religious bigotry, regionalism, tribalism, ethnic sentiments and acts of brigandage as witnessed in the utterances of some delegates in the 2014 national conference. Relegation of public interest, malpractices of all forms, crimes of every description, mendacity, lack of candour, readiness to cheat, grabbing, philistinism, ethnic and sectional inclinations are the only game in town. All these have precipitated social dislocation, insecurity, violence, abject poverty, socio-economic and political instability. National integration has been elusive, yet it is needed to achieve the universal goal of development, that is, the pursuit of people's material welfare and wellbeing. A society that is unjust and devoid of equity and equality will inherently be unstable.

Since the return to civil rule in 1999, Nigeria government has taken some steps to address the twin challenges of corruption and bad governance in the country. These measures include public service reform such as monetization to reduce waste and reduction of over bloated personnel, reform of public procurement; establishment of Anti-corruption enforcement agencies such as the Economic and Financial Crime Commission (EFCC), Independent Corruption and other Practices Commission (ICPC) etc. Despite the successes achieved by these measures, the situation remains unacceptable as corruption and bad governance continues to pervade every facet of national life. More worrisome is that in spite of popular anger against corruption and bad governance, which have robbed the collective wellbeing of the people, there remains a lack of national consensus on repulsion against the perpetrators irrespective of their ethnicity, religion, class and gender. Yet, the emergence of popular movements that is capable of galvanizing the palpable rage of the people and channel it to series of actions and outcomes that could challenge the status quo appears to be lacking. 
While the ranks of unemployment and its attendant poverty increases at one extreme, the number of private jet owners grows in arithmetic progression at the other end. Excruciating poverty exists side by side with obscene opulence. For instance, according to National Demographic Health Survey (NDHS), the maternal and newborn mortality and morbidity in Nigeria is one of the highest in the world, with an estimated 545 maternal deaths for every 100,000 live births. 158 of every 1,000 children fewer than five years of age die of preventable diseases yearly (see The Nigerian Tribune, 2013; Orude, 2014). Almost 70 percent of the population lives on less than $\$ 170$ per day while life expectancy stands at 52 years. According to United Nations Children Fund (UNICEF), Nigeria has the largest number of out of school children (10.5 million) in the world (see Daily Sun, 2014).

Corroborating this unfortunate scenario, Igbokwe-Ibeto \& Okoye (2014), succinctly argued that Obasanjo's civil regime expended $\$ 16$ billion on generating darkness for the country while the same regime is yet to account for $\$ 20$ billion diverted from the federation account. Insecurity is now a way of life despite the trillions of naira claimed to have been spent on security. The current wave of insecurity can partly be traced to the army of jobless youths. For example, the National Bureau of Statistics (NBS) recently alerted that 54 percent of Nigerian youths are unemployment (Agboola, 2014), meaning that the country is seating on a cake of gun powder.

Also, the national airline (Nigeria Airways) has since 'disappeared' on the raider to allow for private airlines; the Power Holding Company of Nigeria (PHCN) has being 'killed' to boost the business of power generators; the Nigeria Telecommunication (NITEL) has 'vanished' for private ones to spring; the railway was 'incapacitated' to enable private haulage to flourish; the federal and state universities are in 'comatose' so that private ones can emerge; and stolen public funds are spent to import weapons to fuel insecurity and suppress political opponents (see for example Olayiwola, 2013; Abbas, 2012).

It would seems, all boils down to corruption accessioned by leadership deficit and bad governance in the country. There is lack of critical mass of men and women of integrity willing to harness and unleash the various resources in the country for the common good or public interest. The paper therefore, seeks to unravel the forces which provoke these states of affairs by interrogating the devastating problems of leadership failures and the enigmatic nature of corruption and bad governance which have arrested socio-economic and political development in Nigeria over the years.

\section{Methodology}

The paper adopts qualitative research design to gain an insight into the nature and character of leadership, corruption and governance in Nigeria and the categorical 
imperatives. The researchers used descriptive analysis to examine the issues of leadership, corruption and governance in Nigeria. The paper which is theoretical in nature draws its argument basically from secondary data which include journal publications, textbooks and internet sources. Statistical data were also used where necessary as empirical evidence portraying our argument. To improve on the reliability and validity of the paper, multiple secondary sources were used to minimize risk of error.

To realize these objectives and for ease of analysis, the paper is pigeon holed into the following five compartments: The first compartment chronicled introduction and methodology. The second section examined conceptual and theoretical issues central to the discourse. The third discussed the interface between leadership, corruption and governance. The fourth $\mathrm{x}$-rayed challenges of leadership, corruption and governance in Nigeria. The fifth proffer the way forward in the context of the identified problems; then conclusion and implications.

\section{Leadership, Corruption and Governance: Conceptual and Theoretical Insights}

Some concepts in social and management sciences do not easily lend themselves to universally agreed definitions. This makes every definition perhaps only relevant within the parameters set for a given investigation. The concept of leadership evokes several meanings and studies elaborating different dimension of it abound. Leadership is both the adhesive and catalyst which bind citizens of a given country together and triggers their motivation towards the achievement of individual and group objectives. To Bedeian (1986), leadership is the art of influencing individual or group activities towards the achievement of organizational or societal objectives. Also, leadership involves the inducement of followers by the leader to act for certain goals that represent the values and motivation, the wants and needs, the aspirations and expectations of both leader and followers (Burns, 1978).

After a careful examination of the leadership impasses in Nigeria, Achebe (1983) concludes that:

The trouble with Nigeria is simply and squarely a failure of leadership. There is nothing with the Nigerian land or climate or water or air or anything else. The Nigerian problem is the unwillingness or inability of its leaders to rise to its responsibility, to the challenge of personal example which is the hallmarks of true leadership.

Surely, leadership holds the key to unlocking the transformation question in Nigeria, but to sustain this drive, leaders must carry certain genes and attributes that are representative and promotive of this order. These include: (i) The existence of practical, purposeful, visionary and missionary initiative by the individual, reflecting the objectives of held ideas, values and aspirations, (ii). The existence in an 
individual of a clear set of ideas, values, aspirations reflecting those of the majority who are the subject or followership, and (iii). The existence of patriotic and nationalistic spirit, transparency and accountability, signs of concrete achievements involving the extent to which intended effects are produced by the leader. These are the core values of good governance.

A related concept to leadership is governance. The term 'governance' cannot be pinned down to a universally acceptable definition. This is because it has fallen into semantic predicament to the extent that the literature on it replete with so many definitions of the term by various scholars with different variant and subtype. However, we shall comb the conceptual terrains of the term with a view to finding the middle ground for its heuristic investigation. According to the United Nations Development Programme (UNDP, 2011) governance is defined as "the exercise of economic, political and administrative authorities to manage a country's affairs at all levels". Similarly, the World Governance Survey Report conceptualized governance as "the formulation and stewardship of the formal and informal rules that regulates the public realm, the arena in which state as well as economic and social actors interacts to make decisions (in Hyden \& Court, 2002).

Recently the terms "governance" and "good governance" are being increasingly used in development literature. Bad governance is being increasingly regarded as one of the root causes of all evil within our societies. Major donors and international financial institutions are increasingly basing their aid and loans on the condition that reforms that ensure "good governance" are undertaken. Good governance has some characteristics which include: It is participatory, consensus oriented, accountable, transparent, responsive, effective and efficient, equitable and inclusive and follows the rule of law. It assures that corruption is minimized, the views of minorities are taken into account and that the voices of the most vulnerable in society are heard in decision-making (Akhakpe, 2014). It is also responsive to the present and future needs of society (Downer, 2000).

Politically, good governance entails the establishment of a representative and accountable form of government; good governance requires a strong and pluralistic civil society, where there is freedom of expression and association; good governance requires good institutions - sets of rules governing the actions of individuals and organizations and the negotiation of differences between them; good governance requires the primacy of the rule of law, maintained through an impartial and effective legal system; and good governance requires a high degree of transparency and accountability in public and corporate processes.

Economically, good governance requires policies to promote broad-based economic growth, a dynamic private sector and social policies that will lead to poverty reduction. Economic growth is best achieved in an efficient, open, market- 
based economy. Investment in people is a high priority, through policies and institutions that improve access to quality education, health and other services that underpin a country's human resource base. Effective institutions and good corporate governance are needed to support the development of a competitive private sector. For markets to function, social norms are needed that respect contract and property rights.

Yet, careful management of the national economy is vital in order to maximize economic and social advancement. Governance comprises the mechanisms, processes and institutions through which citizens and groups articulate their interests, exercise their legal rights, meet their obligations and mediate their differences. Good governance means competent management of a country's resources and affairs in a manner that is open, transparent, accountable, equitable and responsive to people's needs. All these factors in the view of Akhakpe (2014) combined determine the level of development in a given society.

This brings us to the vexed issues of development. The term development has endured conceptual and methodological shift over the years. In the 70s, development was associated with issues of growth in the economy, rise in per capita income and increase in Gross Domestic Product (GDP). However, Todaro (1982) provides a parameter for interrogating the issues of development. For him, objectives of development should include: ability to meet basic needs such as food, shelter, health and protection, achievement of self-esteem and human freedom. Todaro went further to argue that society deserves human freedom in form of emancipation from alienating material conditions of life and freedom from the social servitude of man and ignorance of nature, misery, institutional and dogmatic beliefs.

Corroborating the above view, Eberlee (2001) argued that in contemporary times, the concept of development has moved away from the fetishism of growth and development to the ability of a people to recover their resources and use same according to its cultural values to solve their individual and collective problems to bring about new frame of life where each stage is an improvement on the preceding one. What is at stake in Africa is the lack of development of man's wellbeing and welfare due to poverty of leadership and bad governance which has given rise to monumental corruption.

The term corruption belongs to the 'tribe' of disputed concept as social and political analysts strive to explore its variegated nature and meaning. Etymologically, the word "corruption" originates from the Greek word "corruptus" meaning an aberration or a misnomer. However, in Nigeria today, corruption has become so common a word that it's actual meaning need no explanation to an average citizen. Waziri (2010) citing the United Nations Global Programme against Corruption (GPAC) defines corruption as "abuse of power for private gain". Transparency 
International (2013) has chosen a clear and focused definition of the term as "the abuse of entrusted power for private gain". It can also be defined simply as a perversion or change from the general accepted rules or laws for selfish gain.

Corroborating the issues on high rate of corruption in the polity, IgbokweIbeto \& Okoye (2014), argued that since gaining independence in 1960, most Nigerian leaders have not clearly demonstrated sense of genuine national development. They went further to argue that most African leaders plunder, defraud, embezzle and mismanage their countries human and natural resources with so much impunity. They are possessive, egoistic, selfish, individualistic, callous, greedy and secretive that transparency and accountability has no place in their administration and management of common and collective wealth (Igbokwe-Ibeto \& Okoye, 2014). For example, the official figures recently published by the Nigerian Bureau of Statistics (NBS), capture and underscore the paradox of the Nigerian situation. The figures show the copious inflow of proceeds from oil and the very sharp contrast between available resources and the living conditions of the citizens. The Bureau's report like many others has drawn public attention to the hydra headed and repugnant virus of mismanagement and leadership failure (see The Nigerian Tribune, 2013).

It is along this line of thought that Adebanjo (2008) gave an insight that an estimated $\$ 380$ billion of the country's collective wealth was stolen by its postindependence leaders: about two-thirds of all economic aids given to Africa during this period. Also, the regime of Ibrahim Babangida was unable to account for $\$ 12.4$ billion of missing oil revenues that were part of a windfall from the 1991 Gulf War (Apter, 2005). Corruption is an evil wind that affects everyone and retard societal progress. While there are several theories that explain its prevalence in society, the point to emphasize is that it has become a way of life in Nigeria. This explains why it has been difficult to combat its rising profile.

The subject matter of the paper could be predicated on several theoretical platforms, especially in the social and management sciences where perspectives often differ based on a scholar's orientation and worldview. It is in the light of the foregoing that we undertake this endeavour. When issues of leadership, corruption and governance are mentioned in contemporary times, the political culture, elite theory, theory of two publics and nature of society theories come to mind. While other theories may be relevant in their right, we anchor the paper on the nature of society approach and theory of two public. Indeed, "there is virtually no subject that one considers in Africa without emphasizing the role of the state" (Osaghae, 1988). This is so because the state not only leads, it also embodies the society in Africa. One fundamental fact to note from the onset is that the Nigerian state, like most African states and Third World countries is a product of colonialism. 


\section{The Interface between Leadership, Corruption, Governance and the Theory of Two Public}

Many scholars of African descent and politics such as Osaghae (1988) and Ekeh (1975) have traced the problem of leadership and corruption in Africa to the debauchery of colonialism. Theory of two public is credible not only in the understanding of the state and its predicaments in Africa but also in providing important explanations for the pandemic leadership deficit, corruption and bad governance ravaging African countries. Ekeh (1975) argued that one of the most striking impacts of colonialism was the emergence of two public realms, the primordial and civic public realms which related differently with the private realm in terms of morality. For Nigeria in particular and Africa in general, Ekeh argued that only rights (i.e. benefits) are expected from the state by its citizens, who owe duties (responsibilities) to a native sector. The former forms the basis of an "amoral civic public realm" and the latter a "moral primordial public realm". Therefore, the civic public realm was associated with illegitimate and exploitative colonial rule and had no moral linkages with the private realm. It was an amoral public realm in which cheating the system was considered a patriotic duty (Ifidon, 1996).

The result is that as the same actors operate in the two realms, the state apparatus is employed to fatten the nest of the primordial public, thereby making corruption, nepotism, impunity and ethnicity to mention a few the hallmark of the civic public (Osaghae, 1988). According to Ekeh (1975),

A good citizen of the primordial public gives out and asks for nothing in return; a lucky citizen of the civic public gains from the civic but enjoys escaping giving anything in return whenever he can. But such a lucky man would not be a good man when he channels all his lucky gains to his private purse. He will only continue to be a good man if he channels part of the largesse from the civic public to the primordial public. That is the logic of the dialectics. The unwritten law of the dialectics is that it is legitimate to rob the civic public in order to strengthen the primordial public.

Dudley (in Akhakpe, 2014) made one of the elaborate attempts at explaining the political behavioural and institutional patterns and nature of societies in terms of Weberian postulations on individuals and collective values embedded in their culture. The central thrust of Dudley's perspective is on the impact of the country - wide premium placed on wealth and status on politics. In Nigeria for example, there is the use of political office to enrich one's self. This is not seen however as corruption in as much, as the person involved is seen as contributing such ill-gotten wealth to the welfare and development of his or her community (Osaghae, 2011). In addition, Osaghae (1994) stresses that the material perception of the state has made the 
political elite to seek for power mainly to enrich themselves and members of their groups. The reason why people seek power is not to further the ends of the people and community but that of self.

The relevance of the theories to this paper is that it has provided a framework for understanding the wide gap between the (leaders) civic public and the (followers) primordial public. These disconnect between the leaders and the citizens are evident. The leaders did not emerge from among the people; rather they were imposed on them by godfathers and political parties. Since the elected officials are not accountable to the people, the leaders engage in corrupt act and bad governance with impunity at the expense of the ordinary citizens. On the other hand, due to the nature of the society, a corrupt official remains a good man as long as he channels part of the money he or she stole to satisfy ephemeral yearnings of a few, jettisoning programmes and projects that will improve the life of the people.

\section{Challenges of Leadership, Corruption and Governance in Nigeria}

Several normative and empirical obstacles inhibit bureaucratic leadership in its efforts at promoting good governance and fight against corruption in a developing country like Nigeria. In what follows, we shall dwell on these challenges with a view of providing a road map for ameliorating, if not eradicating them.

The spirit of patriotism and nationalism in Nigeria and Africa in general seem to have gone with the attainment of political independence. Ever since then, African leaders hardly pursue the goals of the state but their own personal and sectional interest. To exemplify this, is a statement credited to President Goodluck Jonathan that the dreaded Islamic fundamentalist group 'Boko Haram' has infiltrated his government. This bewildering statement is an indication that some cabinet members are there to pursue interest antithetical to that of the nation, thus, in these circumstances the issue of leadership and good governance remains a mirage. The unguided utterances and position of some delegates in the 2014 National Conference attest to this fact.

The materialistic thesis and perception of the state in Africa and its institution is a hydra headed problem that has robbed the society of it leadership and governance essences. The state in Africa is seen as an avenue of primitive wealth accumulation. This notion and virus has affected the conduct of government business and regrettably has crept into the whole society. Banfield (in Osaghae, 1994) argued that the only reason people in this kind of society seek public office is to pursue their material gain and in the process neglect public wellbeing and interest. For example, Mobutu Saisasiko a former President of Zarie now Democratic Republic of Congo once told a bewildered nation "that it is not a crime to steal government money, only when you steal, steal small-small, and invest it in the country but you become an 
enemy of the state when you steal and invest outside the country" (see Akhakpe, 2014).

Yet, Nigeria and most African countries are plural societies with multi-ethnic and religious group. This throws up another problem in areas of representations at the federal, state and local government levels. One of the measures put forward to manage these diversities in Nigeria is the federal character principle. However, whether the principle has done well overtime is a different subject matter. But suffice to say that the application of federal character with tense ethnic relations have vitiated the value of merit with its attendant poor performance and service delivery in the public sector (Akhakpe, 2014).

Policy inconsistency, government instability and over reliance on foreign ideas to tackle domestic problems are common phenomenon and bane of effective leadership and good governance in Africa. Leaders hardly sustain the policies and programs of their predecessors; cabinet reshuffle is often expected because government is expected to be representative of all interest in the country. African leaders pursue non indigenous policies with little or no knowledge of their application and implications.

While in developing countries desirous of development, corrupt practices by government official and leaders attract death penalty, in Nigeria and Africa in general, instead of tightening the punishment for corruption, it is been weakened by the so called 'plea-bargain'. For instance, some former governors who were indicted of stealing and miss-managing state funds escape punishment through this window of the law. The legal frameworks dealing on issues of corruption and bad governance should be redesign to be no respecter of any one no matter how highly placed while the existing laws should be activated.

Corruption in Nigeria has become so pervasive to the extent that young men and women do not see the essence of doing the right thing or going to school to learn because they see daily how illiterates and half-baked educated ones control billions of naira while the highly educated once conducting research that is contributing to advancement of knowledge and the society are looked at with scorn. In this context, the people can hardly believe and respect their leaders.

Indeed, the commercialization of religion in Nigeria is now a permanent feature of our religious landscape. One can say with some measure of certainty that most of those who profess faith among the Christian and Muslim worshippers are actually faithless. Both the Bible and Qur'an say, the fear of God is the begging of wisdom. Donations are taken from followers without caring how the monies were gotten. Religious titles are awarded to the highest bidders while the universities award 
honorary doctorate degrees to leaders without questioning the moral credentials of the beneficiaries.

The mass media and professional bodies in Nigeria are not helping matters. It appears a number of them are set up with money acquired through corruption and therefore, see nothing wrong in stealing of public fund. Most professional bodies in Nigeria are concerned about how their members could benefit from what goes on in the polity, rather than ask questions on how public officials openly live above their legitimate income. In other clients the mass media and professional bodies serve as the watch dog and whistle blowers against corruption and bad governance. Is high time we investigate the owners of private newspapers, television and radio stations across the country with a view to ascertain their sources of the funds.

Flowing from the above points, it is clear why the issues of leadership, corruption and governance will for long remain an issue of debate in Nigeria. Here lie the imperatives of transformational leadership. Leadership at the government level is therefore seen as the cause and effect of the country's development predicaments. It would appear that once public offices are personalized, leaders tend to distance themselves from the people they ought to serve. In this context, governance essences are ignored as service delivery, transparency and accountability takes the back burner. People engage in corrupt practices and all sort of unethical behavior to help themselves. How do we break from the cycle in Nigeria? These we shall address in the section that follows.

\section{Leadership, Corruption and Governance in Nigeria: The Categorical Imperatives}

We have identified challenges facing Nigeria in its efforts to promote effective leadership and good governance and fight corruption. On a prima facie basis, these challenges may appear huge and complex. Yet, they are not insurmountable. With concerted efforts, careful planning and dedication to the course of Nigeria's development, what seem to be ugly situation can be turned around for the good of all. In this section of the discourse, we shall examine some steps which could be taken to promote god governance through the instrumentality of effective leadership that could nip corruption on the board.

Leadership holds the key to unlocking some of the major challenges confronting Nigeria and Africa in general. The corporate interest of the state should be made to cohere with those of the leaders. In as much as they do not, leaders can hardly use their position, creative talents and abilities for the benefit of common good. As Olugbemi (1979) puts it, insofar interest of the Nigerian state are distinguishable from the collective and or sectional interest of the leaders, Nigerian leaders will exploit its roles to further and protect its corporate interest. Leaders are 
agents of transformation anywhere in the world. They bring about social change in all aspects of the societal life. They must be good listeners, visionary and missionary, patriotic and nationalistic, be prepared to serve and not to be served among others.

In this stage of the nation's live, the need for a transforming or transformational leadership as well as servant or caring leadership styles cannot be overemphasized. The theory of transforming or transformational leadership as postulated by Burns (1978) rests on a set of assumptions about the relationship between leaders and followers. Burns (1978) and Ciulla (1978) argued that leaders have to operate at higher need and value systems and play the role of raising people's consciousness". Transforming leaders are reputed for their strong value and moral ideals which they do not water down by consensus but elevate people by using conflict to engage followers and help them reassert their own values and needs. Such leaders are concerned about liberty, justice and equality and transforming leaders raise their followers up through stages of morality and need. Like servant leaders they turn their followers into leaders and the leader becomes a moral agent (Olayiwola, 2013).

The establishment of democratic government is an anti-corruption strategy. Theoretically at least, the dispersal of power within the institutions and processes of democratic government should constrain possibilities for venality. The accompanying protection of civil liberties and human rights should make for open and transparent government and provide a check on abuse of power (see Odinkalu, 2010). Competitive politics under-pinned by periodic renewal through elections of the mandate to govern should reward politicians with a credible record of protecting the public resources and interest. Together, these three occurrences - dispersal of power, institutions accountable to government, and competitive electoral politics for periodic renewal of government's mandate- are essential elements of democratic government as an anti-corruption strategy

In the present era where emphasis is on governance, service delivery, transparency and accountability are the game in town and every one need to key into it. As desirous as good governance can be, it cannot be brought to bear on leaders by mere slogan. The features of leadership and good governance should be infused into their psyche and made a way of life in the society.

There is need for fear of God, which is the beginning of wisdom. However, in Nigeria, the reverse is case, the more the number of places of worship (mosques and churches), the higher the incidence of bad leadership, corruption and bad governance. A peep into the activities of various Pilgrims Welfare Boards and Commissions both the Christian and Muslim ones, will reveal to a keen observer, that corruption is not even a respecter of religion or faith. The religious groups encourage corruption in different forms. Some preach prosperity without accountability. 
Nigeria faces an existential crisis located at the nexus of governance and corruption. To fix this problem, it is imperative to diagnose it properly and then confront it collectively. As Nigeria marked (2014) her centenary celebration i.e. 100 years of amalgamation of the North and Southern Nigeria, within and outside Nigeria, the question should be: How has a country so richly endowed blown the opportunities for itself and its generations yet unborn so spectacularly? To adapt Cassius in Shakespeare's Julius Caesar, it is not difficult to argue that the fault is not in our stars, but in ourselves, that we have such a crisis with leadership, corruption and bad governance". The good news is that having got here as a people, we owe ourselves a duty to get ourselves out of the mess. The bad news is it will not be easy and the situation admits of no magic wind or quick fixes. To begin the journey of fixing our country, we must first tell ourselves some inconvenient truths.

Orientation and re-orientation of leaders and followers alike should be made a continuous exercise. Best values and practices in globe should be internalized in Nigeria and Africa in general. Indeed, it would appear that the problem has often been the gap between words and action. Nigerian leaders should match their words with action. Be stable and consistent in its policies and programmes. Then, the people will believe the government/leaders and follow suit by performing their obligatory and non obligatory duties and responsibilities.

The culture of a society can develop or hinder their development. The perception of corruption as an amoral act stems from the fact that too many Nigerians still see the state an abstraction meant to brutalize and not to cater for the socioeconomic and political well-being of its citizens. This notion can only be jettisoned through effective leadership and good governance.

Corruption has been the focus of considerable attention, hand-wringing and lamentation in and outside Nigeria. Some of the best known public advocacy and international organizations in the world, including Transparency International - exist to combat it while on the home front we have Independent Corrupt Practice Commission (ICPC) and Economic and Financial Crime Commission (EFCC). We do not claim any special insights on this issue. In addressing the issue of corruption, we propose to reflect our own personal viewpoints and the experiences as Nigerians. Corruption has continued to defy all possible solutions in Nigeria because the cost of corruption is too cheap and the political will to implement anti-corruption laws is absent (Igbokwe-Ibeto \& Okoye, 2014). They went further to argue that poorly and inappropriate institutional frameworks are responsible for a significant level of the opportunism that has pervaded the Nigerian state since independence. To North (1990), "institutions are the humanly devised constraints that shape incentives in human exchange, whether political, social, or economic". Institutional change shapes 
the way societies evolve through time, and hence, is the key to understanding historical change.

It will be difficult to address the problems of leadership, corruption and bad governance in Nigeria in isolation of the rest of Africa. Indeed, leadership failure, corruption and bad governance is not just a Nigerian problem; it is a problem for Africa's for development to which African countries collectively lose an estimated 25 percent of GDP or about \$148 Billion annually. Nigeria merely illustrates to scale a problem that every African and indeed developing country also confronts.

Yet, the poor economy of Nigeria must be addressed. There is no gainsaying the fact that there is high rate of poverty in Nigeria. This poverty is linked to so many factors such as lack of employment, underemployment etc. It is a common knowledge that the Nigerian economy has seriously suffered the global economic meltdown which has really adversely affected labour market. This has largely contributed to massive retrenchment at both private and public sectors of the economy. Therefore, as a survival measure, a typical Nigerian has to look elsewhere to meet up with his/her responsibilities. So when any slight opportunity comes his/her way to embezzle public or private treasury as the case may be, he or she grabs it with both hands.

With effective leadership, eradication or minimization of corruption to the barest minimum as well as good governance, the Nigerian state will be able to perform the functions of a normal state. In this context, we are referring to the basics of contemporary human existence such as shelter/housing, healthcare, security, food, peace, jobs/employment, education for all, and public transportation.

Also, we advocate for confiscation of properties of public officials found to be involved in wrongful corrupt acts; death penalty for embezzlement and siphoning of state money abroad; jail sentences without fine option for offenders of corrupt practices and bad governance; cancellation of election results obtained based on rigging and fraudulent acts; disqualification of public officers implicated in election and allied mal-practices; and public disgrace and life jail for corrupt business men and women feeding fat on public fund.

Also, civil society in Nigeria should be linked both at the level of ideas and practice. As it stands, there is so much individualism in the operations of civil society organizations. For broader reach and positive impact, "civil society organizations working in different sectors such as reproductive rights and health, environment, human rights, youths and so on, need to be encouraged to work together and to develop common platform for intervention and participation in shaping policies. It is not in doubt that Nigeria has a large number of civil society groups, some claim to be anti corruption bodies. But it seems some of these civil society groups have been 
infiltrated by corrupt officials. The infighting and the scramble for the spoils of offices or what can be called 'stomach infrastructure' are evident in many of these civil society groups.

\section{Conclusion and implications}

In sum, we have dwelt extensively on the issues of leadership, corruption and governance in Nigeria as captured by scholars and social commentators with an attempt at clarifying the intellectual "cobweb" surrounding leadership, corruption, governance and the categorical imperatives. In addition, searchlight was also beamed on the theoretical framework for a better understanding of the concepts under interrogation. Thus, different theories on the concept of leadership, corruption and governance have been espoused as postulated by scholars. An attempt has also been made to establish the nexus between leadership, good governance and development in Nigeria. Leadership deficit, corruption and bad governance have been an endemic disease, which affects the growth and survival of the Nigerian state and Africa as a continent. The United Nation Human Development Index (HDI, 2011) has put the poverty level of Nigeria to be about $64.7 \%$ and as such, majority of the Nigerian population are said to be living under abject poverty.

It is the position of the paper that the most daunting challenges militating against Nigeria and Africa's quest for transformation appears to be ineffective leadership, untamed and seemingly untamable corruption and bad governance. Based on these, we have made some recommendations that if religious followed and adhered to, could resolve the hydra headed leadership, corruption and catalogue of bad governance problems in Nigeria.

Finally, the paper highlighted a number of challenges which have varied implications on the quest to resolve the transformation question in Nigeria. One of such implication is that, until Nigerian leaders begin to think Nigeria and begin to 'plant trees' whose shades they know they shall never seat in, the quest for good governance and efficacious leadership that could fight corruption and engender sustainable socio-economic and political development will for long remain a mirage. 


\section{References}

Abbas, F. (Jan. 20, 2012). The Message. The Nation, p. 36.

Achebe, C. (1983). The trouble with Nigeria. Enugu: Fourth Dimension Publishers.

Adebanjo, A. (2008). Hegemony on a shoestring: Nigeria's post-cold war foreign policy. In Adebanjo, A. \& Mustapha, A. R. (eds.), Gulliver's troubles: Nigeria's foreign policy after the cold war. Pietermaritzburg: University of Kwazulu-Natal Press.

Agboola, T. (2013). 54\% of youths jobless, says NBS. The Nation. Monday, December 23, p.36.

Akhakpe, I.I. (2014). Bureaucracy and good governance. Lagos: Pumark Nigeria Limited.

Apter, A. (2005). The Pan-African nation: Oil and the spectacle of culture in Nigeria. Chicago: University of Chicago Press.

Bedeian, A. G. (1986). Management. Chicago: The Dryden Press

Burns, J. (1978). Leadership. New York: Harper Torch Books.

Ciulla, J. (ed.) (2004). Ethics, the heart of leadership. London: Praeger.

Downer, A. (2000). Good governance: Guiding principles for implementation. Canberra: AusAID.

Eberlee, J. (2001). Enhancing the role of traditional leaders in African governance. IDRC Report.

Ekeh, P.P. (1975). Colonialism and the two publics in Africa: A theoretical statement. Comparative Studies in Societies and History, 19(19): 12-27.

Hyden, G \& Court, J. (2002). Comparing governance across countries and time: Conceptual challenges. In D. Olowu \& S. Bako (eds.) Better governance and public policy. Bloomfield: Kumarian Press.

Ifidon, E. A. (1996). Citizenship, statehood and the problem of democratization in Nigeria. African Development, 21 (4): 93-107.

Igbokwe-Ibeto, C.J \& Okoye, J. C. (2014). Anti-corruption crusade in Nigeria: More words than deeds. International Journal of Public Policy and Administration Research, 1(2):47-63

North, D.C. (1990). Institutions, institutional change and economic performance. Cambridge: Cambridge University Press. 
Odinkalu, C. A. (2010). Corruption and governance in Africa: How do we break the cycle in Nigeria? A paper presented on corruption and governance challenges in Nigeria, Conference proceedings, Cleen foundation monograph series. No 7

Olayiwola, A.R.O. (2013). Leadership, corruption and governance in Nigeria. Journal of Education and Leadership Development, 5(2):52-73

Olugbemi, S. (1979). The civil service, an outsider's view. In Oyediran, O. (ed.) Nigeria government and politics under military rule 1966-77. London: The Macmillan Press.

Orude, P. (2014). Maternal, infant deaths ravage Adamawa ... As EU, UNICEF battle menace. Daily Sun Wednesday, July 16, p.23.

Osaghae, E. (2011). The crippled giant: Nigeria since independence. Ibadan: John Achers Publishers

Osaghae, E. (1994). Introduction: Between the individual and the state in Africa: The imperative of development. In Osaghae, E. (ed.) Between state and civil society in Africa. Dakar. Code Sira

Osaghae, E. E. (1988). Legitimacy crisis, the character of the state and social mobilization in Africa: An explanation of form and character. In Tyoden, S. G. (ed.) Democratic mobilization in Nigeria: Problems and prospects. Proceedings of the fifteenth Conference of the Nigerian political science association, Held at the University of Ibadan June 26 to July 1 st 1988.

The Nigerian Tribune, 4 April, 2013, P. 17

Transparency International, (2013). Nigeria's corruption ranking index.

Todaro, M. P. (1982). Economic development in the World. New York: Longman Press.

United Nations Development Programme (UNDP) (2011). Nigerian human development report 2010/2011 Millennium Edition, Lagos: UNDP

Waziri, F. (2010). Chairman's remarks on corruption and governance challenges in Nigeria. Conference proceedings. Cleen foundation monograph series. No 7 